\title{
The experience of mothers caring for their teenage daughters' young children
}

\author{
N Modungwa \\ M.Cur \\ Rand Afrikaans University
}

$\&$

M Poggenpoel

Ph.D

Rand Afrikaans University

$\&$

\author{
A Gmeiner \\ D.Cur
}

Rand Afrikaans University
"Teenage pregnancy and parenthood continue to haunt modern society into the 1990's. This is despite the availability of modern and effective technology for birth control."

\section{Abstract}

The purpose of this study was firstly to explore and describe the experiences of mothers who are looking after their teenage daughters' young children. Secondly, to formulate guidelines (based on the results obtained) for psychiatric nurses in assisting these mothers to mobilise resources in order to promote, maintain and restore their mental health as an integral part of health. An exploratory, descriptive, contextual and qualitative design was used and Guba's model for ensuring trustworthiness in qualitative research was applied. The phenomenological approach was used to collect and analyse data from a sample of seven respondents who were purposively selected. Three independent themes emerged from the analysis of results: Meaning of the parenting role, life-style changes and support systems. The results further show that for these mothers the problem of teenage pregnancy and parenthood ends up being their problem. Their experiences in looking after these babies, although sometimes fulfilling and meaningful, are most of the time stressful. This has implications on their mental health. Guidelines are recommended in order to facilitate these mothers to mobilise their resources for mental health.

\section{Opsomming}

Die doel van hierdie studie was eerstens om die belewenis van moeders wat die jong kinders van hul tienerjarige dogters oppas, te ondersoek en beskryf. Tweedens om riglyne te beskryf (gegrond op die verkreë bevindings) vir psigiatriese verpleegkundiges om hierdie moeders te help om bronne te mobiliseer ten einde hul geestesgesondheid te bevorder, te handhaaf en te herstel as ' $n$ integrale deel van gesondheid. ' $n$ Verkennende, beskrywende, kontekstuele en kwalitatiewe ontwerp is gebruik, en Guba se model om vertrouenswaardigheid in kwalitatiewe navorsing to verseker, is aangewend. 'n Fenomenologiese strategie is gebruik om data van ' $n$ steekproef van sewe respondente wat doelgerig gekies is, te versamel en te verwerk. Drie onhafhanklike temas het by die analise van gegewens na vore getree: Betekenis van die ouerskaprol, veranderinge in die lewenstyl en ondersteuningstelsels. Verder toon die resultate dat die probleem van tiener swangerskap en -ouerskap uiteindelik in die skoot van die tiener se moeder val. Hul belewenis van die versorging van hierdie babas, alhoewel soms vervullend, is meestal stresvol. Riglyne vir psigiatriese verpleegkundiges om hierdie moeders te help om hul bronne vir geestesgesondheid te mobiliseer word ten slotte beskryf.

\section{Introduction}

Teenage pregnancy and parenthood continue to haunt modern society into the 1990's. This is despite the availability of modern and effective technology for birth control.

While the situation applies to both developed and developing countries, it is the latter countries that are hit the hardest (Ojwang \& Maggwa, 1991:74). In African countries the rate of teenage pregnancy ranges between 10.5 to 51 per cent (Kooma in Sowetan, 1992:15). In South Africa there is also evidence that teenage pregnancy has taken on alarming proportions, particularly among coloured and Black communities (PrestonWhyte, 1991:7).

A lot has been written on the problems associated with early childbearing. One of these problems is that the teenage unable to play a parenting role. The onus then falls on the mother or mother figure to the teenage mother (particularly among Blacks) to take over this parenting role (Burman \& PrestonWhyte, 1992:231).

Research on the problems of teenage pregnancy and parenthood tended to focus solely on the teenage mother and her child(ren). The mother of the teenage mother is seldom focused on. This, despite her daily involvement in bringing up her teenage daughter's child(ren).

The result of this systematic omission by researchers and the popular media, is the absence of mothers of teenage mother, for one reason or another, is 
mothers as a target group in mental health care programmes. This despite the fact that studies have indicated a relationship between parenting of young children and stress (Beautrais, Fergusson \& Shannon, 1982; Baltenski \& Cook, 1982; Boulton, 1983).

This evidence from literature raised the following research questions:

$>\quad$ How do mothers in a certain village in the Molope region experience looking after their teenage daughters' young children while these daughters pursue their developmental tasks?

What guidelines can be developed by an advanced psychiatric nurse practitioner for a support programme for these mothers in order to assist them to mobilise resources to facilitate the promotion, maintenance and restoration of their mental health as integral part of health?

\section{Purpose And Framework}

The purpose of this study was firstly to explore and describe the experiences of mothers who have to take care of the young children of their teenage daughters; secondly to describe guidelines for the advanced psychiatric nurse practitioner to assist these mothers in mobilising their resources to facilitate the promotion, maintenance and restoration of their mental health. The Nursing for the Whole Person Theory was used as theoretical framework to reflect the results obtained from the research (Oral Roberts University, 1990-1992:136-142, Rand Afrikaans University: Department of
Nursing Science, 1992:36-41). This theory views the teenager and the mother of the teenager as spiritual beings who function in an integrated biopsychosocial manner to achieve their quest for mental health (wholeness) by the mobilisation of resources.

Both their environments consist of interacting dimensions, namely physical, social and spiritual, which determine their health status. Physical dimension refers to all bio-physio-chemical processes. Psychological dimension refers to the carrier of all experience and behaviour and it includes all intellectual, emotional and volitional processes. Social dimension refers to the organisational structures among people and communities, in other words all human resources. The spiritual dimension refers to significant spiritual elements or occurrences in the

\section{Table 1 : Strategies to ensure trustworthiness*}

\begin{tabular}{|c|c|c|}
\hline STRATEGY & CRITERIA & APPLICABILITY \\
\hline \multirow[t]{6}{*}{ Credibility } & Prolonged engagement & $\begin{array}{l}\text { Involved in community. } \\
\text { Initially spend time with respondent before interview to build } \\
\text { rapport. } \\
\text { Again allow time for respondent to verbalise experiences. }\end{array}$ \\
\hline & Reflexibility & Taking field notes. \\
\hline & Member checking & $\begin{array}{l}\text { Follow-up interviews with participants. } \\
\text { Literature control on parenting, its impact on guidelines. }\end{array}$ \\
\hline & Peer examination & The services of a colleague will be acquired. \\
\hline & Authority of research & $\begin{array}{l}\text { The researcher has undergone previous training in research } \\
\text { methods. Two doctors in psychiatric nursing, who have experi- } \\
\text { ence in research supervised this study. }\end{array}$ \\
\hline & Structural coherence & $\begin{array}{l}\text { The focus will be on mothers' experiences. Results will be within } \\
\text { Nursing for the Whole Person Theory. }\end{array}$ \\
\hline \multirow[t]{2}{*}{ Transferability } & Nominated sample & The sampling method will be purposive, no. prior selection. \\
\hline & Dense description & $\begin{array}{l}\text { Complete design of methodology and literature control to main- } \\
\text { tain 'transparency'. }\end{array}$ \\
\hline \multirow[t]{4}{*}{ Dependability } & Audit trail & Keeping personal logs and reflexibility notes. \\
\hline & Dense description & Research methodology fully described. \\
\hline & Peer examination & $\begin{array}{l}\text { Independent checking by colleague (devil's advocate) and su- } \\
\text { pervision by experts. }\end{array}$ \\
\hline & Code-recode procedure & $\begin{array}{l}\text { Consensus discussion between researcher and independent } \\
\text { experts. }\end{array}$ \\
\hline \multirow[t]{2}{*}{ Confirmability } & Audit trail & As discussed. \\
\hline & Reflexibility & As discussed. \\
\hline
\end{tabular}

- $\quad$ Adapted with permission from a table used by Poggenpoel, Nolte, Dörfling et al (1994:132) 
teenager and her mother's environment, which includes values, beliefs, norms and ethical principles, religion and meaning in life as well as relationships with others and God.

The data gathered during the study is also reflected within this theoretical framework.

\section{Research Methodology}

An exploratory, descriptive and contextual design was utilised (Mouton \& Marais, 1990:43-44; Burns \& Grove, 1993:29). The research was conducted in two phases. In phase I indepth, semi-structured phenomenological interviews were utilised to interview mothers of teenage daughters. A literature control was done to verify the results. Phase I provided the basis for deduction of guidelines and phase II consisted of the description of guidelines for the advanced psychiatric nurse to support these mothers in mobilising their resources in order promote their mental health. These were also verified by conducting a literature control and discussing these guidelines with advanced psychiatric nurse practitioners.

\section{Sample}

The sampling population consisted of seven mothers looking after their teenage daughters' young children (from birth to 5 years) who live in a certain rural village. Criteria for including participants in the study were: Residence in this particular village, being a mother or mother figure to a teenage mother (not necessarily a biological mother), a primary carer to the young child of the teenage mother, and be conversant in either Setswana, Xhosa, Zulu or English. The method used for selecting the sample was purposive (Burns \& Grove, 1987:218) and participants were interviewed until data was saturated as demonstrated by repeating themes.

Three of these mothers were caring for their own biological daughter's children, while two were grandmothers of the teenage mothers. One of these grandmothers was caring for the baby whose mother was her adopted daughter and one was looking after her daughter-inlaw's baby whose mother abandoned her (in the Black culture a daughter-inlaw is also regarded as a daughter).

Two of the respondents were each looking after two young children of teenage mothers (instead of one). Only three of the seven respondents had husbands of whom only two husbands were employed. They were of low socio-economic status and also had very little

\section{Table 2 : An overview of themes and categories of experience of mothers caring for their teenage daughters' young child(ren)}

\begin{tabular}{|c|c|}
\hline THEMES & CATEGORIES AND SUB-CATEGORIES \\
\hline \multirow[t]{2}{*}{ 1. Meaning of the parenting role } & $\begin{array}{l}1.1 \text { Parenting as a stressor } \\
\text { - Financial distress } \\
\text { - Physical distress } \\
\text { - Emotional-spiritual distress }\end{array}$ \\
\hline & $\begin{array}{l}1.2 \text { Parenting as doing one's duty } \\
\text { - A sense of fulfilment } \\
\text { - Mother-child attachment } \\
\text { - Motivation for taking over } \\
\text { parenting role }\end{array}$ \\
\hline Lifestyle changes & $\begin{array}{l}\text { 2.1 A sense of being trapped } \\
\text { 2.2 Accepting less than ideal standard } \\
\text { of life } \\
\text { 2.3 Job reorganisation }\end{array}$ \\
\hline 3. Support systems & $\begin{array}{ll}\text { 3.1 } & \text { Financial and material support } \\
\text { 3.2 } & \text { Health care support } \\
\text { 3.3 } & \text { Physical assistance } \\
\text { 3.4 } & \text { Strength for sustenance } \\
\text { 3.5 } & \text { Conflict resolution } \\
\text { 3.6 } & \text { Family planing }\end{array}$ \\
\hline
\end{tabular}

material support. Most of these respondents lived in poverty and in overcrowded houses with a seemingly large number of young children.

The teenage mother leaves her child at home whilst continuing her education or other developmental tasks. In this culture, it is then left to the relatives of the teenage mother to bear the burden of supporting and looking after the baby. It is also usually the mother of the teenage girl who then has to care for the baby.

\section{Trustworthiness}

Guba's (in Krefting, 1991:214-222) model for trustworthiness was utilised to ensure the validity and reliability of this qualitative study. The four criteria for trustworthiness were: truth-value, applicability, consistency and neutrality.

Using strategies of credibility by applying strategies of transferability ensured the truth-value. Consistency was ensured by strategies of dependability and neutrality by strategies of confirmability. The criteria and how these were applied in conducting this study, are summarised in Table 1.

\section{Data collection}

Data was collected through phenomenological, semi-structured in-depth interviews, using a tape recorder to record the interviews (Burns \& Grove,
1993:578-581; Minichiello, Aroni, Timewell \& Alexander, 1991:87-129). The aim of these interviews is to allow the participants to speak freely and "in their own terms" about a set of concerns (Ferreira in Mouton \& Marais, 1990:212).

The participants were visited in their homes at least twice before data collection. The first visit was to obtain informed consent and to build rapport. The second visit was again to build rapport and to arrange a date for data collection. A few participants were visited again during data analysis for the purpose of validating some of the interpretations made by the researcher.

A central question was asked: "Please tell me how you experience looking after your teenage daughter's young children". The researcher used facilitating communication techniques such as minimal response, clarification and rephrasing to encourage the mothers to speak openly and freely about their experiences (Minichiello et al. 1991: 167131). The interviews were audiotaped and later transcribed verbatim. The researcher made field notes following the interviews to describe her own observations and experiences during the interview (Minichiello et al. 1991:256).

\section{Data analysis}

A combination of Giorgi's (1985:10-19) 
and Tesch's (in Creswell, 1994:153) descriptive methods of data analysis were used. In addition, the processes of bracketing (suspending preconceived ideas about the experiences of parenting) and intuiting (focusing on the description given by the respondents) as suggested by Spielberg (in Omery, 1983:53) were applied. The steps followed in data analysis were: reading through all the transcripts carefully in order to get a sense of the whole; picking any transcript, reading through it, jotting down some ideas as they come to mind and also identifying the major categories represented in the universum; reading through all the transcripts while underlining units of meaning related to the identified major categories; putting the units of meaning into major categories; identifying sub-categories within the major categories; identifying relationships among the major and sub-categories then reflecting these as themes.

A consensus discussion was then held with an independent coder (who is an advanced psychiatric nurse and also has experience of qualitative research). A literature control was conducted to identify the similarities and differences between this study and previous research. Results were then reflected as patterns of interaction in the respondent's environment within the Nursing for the Whole Person Theory (Oral Roberts University, 1990-1992:136-142, Rand Afrikaans University: Department of Nursing Science, 1992:36-41)

\section{Results and Discussion of Results}

The three main themes that emerged from the respondents' accounts of their experiences were: Meaning of the parenting role, life-style changes and support systems. These themes were further categorised and sub-categorised as depicted in Table 2.

\section{- Meaning of the Parenting Role}

Two major categories emerged from this theme: (i) parenting as a stressor, and (ii) parenting as doing one's duty.

\section{(i) Parenting as a Stressor}

All seven respondents expressed distress in looking after the young children of their teenage daughters. The realisation that looking after young children is stressful is supported in the literature (Brailey, 1985:47; Gordon, 1990:57; Kamerman, 1980:128; Leifer, 1980:230; Liddell, 1989:134-143; Stern, 1989:158; Tam \& Chan, 1994:212; Valman, 1993:3). The distress experienced by respondents was further categorised as: finan- cial, physical and emotional-spiritual.

Financial Distress: All seven respondents expressed financial distress associated with needs such as child health care (6); baby care (4); food or milk formula (4); teenage mother's continuing education (3) and own health care (3).

One respondent put it as follows: " $M y$ life is difficult ... the way this child (teenage mother) burdens me with her child ... A child needs a lot of things, food, clothing, etc. ... My husband gets pension, but I don't know what he does with this money."

In a study of stressors associated with raising pre-school children, mothers mentioned financial burden as an important stressor (Weinberg \& Richardson, 1981:689). In order to fully understand the financial burden experienced by mothers in this study, it is important to mention here other factors that impinge on their experiences:

(a) The village in which these respondents stay is 45 kilometres from town. According to Puskar \& Martsolf (in Fawcett, 1993:212), rural areas are known for their lack of specialised health care services, transportation problems, poverty and high unemployment. The lack of specialised health care services and transport was apparent from field notes. All seven respondents utilise the local clinic for health care needs. Treatment for children under five years of age and the aged is free. However, four respondents stated that the help they get from the clinic is not always enough for meeting their health needs. They sometimes have to pay for transport to get to hospital. They also have to pay private doctors. At other times they use traditional doctors and have to pay for ancestral rituals additionally.

One respondent said: "Last time I had to pay R250 for traditional health consultation." Another one said: "I had to slaughter a goat for the ancestral healing for the baby's sickness." Traditional and folklore medicine is still considered a valued practice among Blacks (Tshotsho, 1994:24-25). Indigenous healing beliefs and practices still form a core part of culture even among Black Americans (Wilson \& Kneis, 1992:917).

(b) The question of income and employment is another factor impinging on the financial burden experienced by these mothers. Only one respondent in this study works for a salary, only two have working husbands, only one is getting old-age pension (although three qualify). The rest live in abject poverty. Other writers have also alluded to the feminisation of poverty (Unger \&
Crawtord, 1984:456; Washington in Birns \& Hay, 1988:206).

Physical Distress: This was mentioned by all seven respondents, specifically general body pains (5); disturbed sleep (5); tiredness (4); and exacerbation of existing physical conditions (3). One respondent said: "Sometimes I have to carry her on my back in order to do housework ... today this one is sick, tomorrow is another one ... by night time I'm so tired ... my body is sore and I can't sleep." Physical distress associated with caring for young children is supported by other studies (Weinberg \& Richardson, 1981:691; Brailey, 1985:47; Miller \& Myers in McCubbin \& Figley, 1983:56).

Emotional-spiritual distress: All seven respondents reported a variety of feelings and concerns: concern with lack of important traditional values by young people (7); bitterness and blaming (6); anxiety and worry (4); anger and annoyance (4); sadness and hurt (4); defeat and helplessness (3); and alienation from others (3). Other researchers have also found that mothers looking after young children experience such feelings (Unger \& Crawford, 1992:440; Boulton, 1983:122; Leifer, 1980:228).

\section{(ii) Parenting as Doing One's Duty}

All seven respondents expressed this theme. They see the role of taking over the parenting role for their teenage daughters as a given or as a natural consequence. "It's alright If she can't look after this baby. After all, I, too, did not raise my first child ... my mother did it. She will be wiser with her second child." one respondent said.

Another one said: "Being the grandmother, I had to look after this child when she abandoned it ... what would people say ... what would God say?" This brings in a normative aspect to the practice of childcare. In our society the duty of raising young children is a woman's responsibility. Several authors allude to the 'gendering of responsibility' for childcare in our society (Hollen, 1982:309; Unger \& Crawtord, 1992:424; Kamerman, 1980:66; Gordon, 1990:49; Boulton, 1983:22).

Referring to the 'motherhood mystique', Unger \& Crawford (1992:431) assert that in our society "being a mother is the ultimate fulfilment for a woman". It is therefore not surprising that these women seem not to question this added role.

The three subcategories that emerged under the category of "parenting as doing one's duty" are: a sense of fulfilment, mother-child attachment and motivation 

Table 3 : Type and sources of support received by mothers caring for their
teenage daughters' young children $(n=7)$

\begin{tabular}{|c|c|c|c|}
\hline $\begin{array}{l}\text { TYPE OF SUPPORT } \\
\text { RECEIVED }\end{array}$ & $\begin{array}{l}\text { NUMBER OF } \\
\text { RESPONDENTS }\end{array}$ & SOURCE OF SUPPORT RECEIVED & $\begin{array}{c}\text { NUMBER OF } \\
\text { RESPONDENTS }\end{array}$ \\
\hline $\begin{array}{l}\text { 1. Financial and material } \\
\text { aid }\end{array}$ & 7 & $\begin{array}{l}\text { 1.1 Other children } \\
1.2 \text { Own means of income } \\
\text { 1.3 Husband } \\
\text { 1.4 In-laws (boy's parents) } \\
\text { 1.5 Pension } \\
\text { 1.6 Salary (own) } \\
1.7 \text { Teenage mother } \\
\text { 1.8 Other relatives }\end{array}$ & $\begin{array}{l}6 \\
3 \\
2 \\
2 \\
1 \\
1 \\
1 \\
1\end{array}$ \\
\hline $\begin{array}{l}\text { 2. Health care and family } \\
\text { planning }\end{array}$ & 7 & $\begin{array}{ll}\text { 2.1 } & \text { Clinic } \\
\text { 2.2 } & \text { Folklore/traditional healer } \\
\text { 2.3 Hospital } \\
\text { 2.4 Private doctors }\end{array}$ & $\begin{array}{l}7 \\
5 \\
2 \\
2\end{array}$ \\
\hline 3. Physical assistance & 7 & $\begin{array}{l}\text { 3.1 Other children } \\
\text { 3.2 } \text { Teenage mother } \\
3.3 \text { Other relatives } \\
3.4 \text { Neighbours } \\
3.5 \text { Babysitter }\end{array}$ & $\begin{array}{l}6 \\
5 \\
3 \\
2 \\
1\end{array}$ \\
\hline $\begin{array}{l}\text { 4. Strength and suste- } \\
\text { nance }\end{array}$ & 4 & 4.1 God & 4 \\
\hline 5. Conflict resolution & 3 & $\begin{array}{l}\text { 5.1 Social worker } \\
5.2 \text { Husband } \\
5.3 \text { Relatives }\end{array}$ & $\begin{array}{l}2 \\
1 \\
1\end{array}$ \\
\hline
\end{tabular}

for taking over the parental role.

A sense of fulfilment: Five respondents expressed a sense of being fulfilled by succeeding under all odds in raising their teenage daughters' young children. They also view the struggle as worth it. For this they feel a sense of pride. This is implicit in this account: "Her mother left her when she was a small, little, frail thing. I struggled to raise her. God was with me. Look at her today ... I've made it."

Mother-Child attachment: During the process of looking after their teenage daughters' young children, a strong bond seems to grow between the respondents and the children. This was the case with all seven respondents. This seems to give these mothers a sense of pride and fulfilment. One respondent said: "Oh, this child is mine. She has nothing to do with the mother ... she is mine." In certain cases bonding between the child and the biological mother was actually discouraged. "What happens if she gets married by another man ... This child is mine." another respondent said.
Motivation for taking over the parenting role: Respondents mentioned various motivations for taking over the parenting role. Five respondents did it in order to allow the teenage mothers to continue with their schooling. Two were forced to take over because the teenage mothers abandoned their babies. The following factors seem to have played an important part in the decisions made by the former group: education as a cushion/ security against an unsuccessful marriage (3); school as a way of keeping the teenager away from mischief, e.g. pregnancy (5) and concern for the welfare of the baby in the light of the teenage mother's apparent lack of parenting skills. One respondent said: "The mother is such a fool. You can't risk leaving the baby with her ... she can't even feed her properly. The other day the baby drank paraffin..."

Deficiency of parenting skills on the part of the teenage mothers has been highlighted in the literature (Loening in Burman and Preston-Whyte, 1981; Sommer, Whitman, Borkowski et al, 1993:391; Brooks-Gunn \& ChaseLansdale, 1991:471.

\section{- $\quad$ Life Style Changes}

This is a second independent theme emerging from the respondents' experiences. This theme was categorised as: (i) a sense of being trapped; (ii) accepting less than an ideal standard of life, and (iii) job reorganisation.

\section{(i) A Sense of Being Trapped}

Six of the respondents expressed a sense of being trapped in one way or another. This sense is conveyed in the following account: "I'm cut off from $m y$ friends. My life is restricted a lot. Let's say I want to go and visit my friends and enjoy a bit, I can't. Maybe sometimes one of your friends has a party. You are sitting there and drinking cold things. Sometimes you drink and drink. The next thing when you come home, there is no cooked food. So it means I have to be here all the time."

Other areas in which respondents felt restricted were: attending church services (2); time to visit boyfriend (1); going to town (3) and being with other people (3). 
This sense of being tied to the home was also mentioned by mothers in a study of women with pre-school children (Boulton, 1983:91). Lack of freedom for yourself, lack of time with spouse and lack of time with other adults were mentioned by women in Weinberg and Richardson's study (1981:689).

(ii) Accepting less than an ideal standard of life

Three respondents complained of this change in their life-style. This is because all available resources had to be rechannelled towards childcare. One respondent said: "Things came to a standstill ... My building project had to stop as the little money available now goes to caring for this baby." In a study of women's perceptions of their current life circumstances since the arrival of a new baby by Eckenrode \& Gore (1990:74), women reported the following: "not having time to tackle big projects around the house as much as they would like to and not being able to spend as they would like to."

\section{(ii) Job reorganisation}

Four of the respondents had to re-organise their jobs in order to accommodate the young children into their daily work schedule. One changed from day to night duty. Two had to leave paid employment.

Weinberg \& Richardson (1984:686) assert that "the birth of a child encompasses a range of experiences over time, including ... the concomitant need for parents to reorganise their ongoing life structure regarding simple life maintenance, social contacts and job demands."

\section{- Support systems}

This is the third theme that emerged from the respondents' experiences. It was categorised into types and sources of support received by respondents while looking after their teenage daughters' young children (see Table 3 ).

Types of support received were further categorised into: (i) financial and material aid; (ii) health care and family planning; (iii) physical assistance; (iv) strength and sustenance and (v) conflict resolution.

\section{(i) Financial and material aid}

All seven respondents raised financial concerns. These were discussed under the section on financial distress. From Table 3, it seems that other children in the family are the major source of support.
One respondent had this to say regarding this form of support: "It's difficult because even this child who gives me money gets very little salary. His job is also not stable ... My mother also is not on pension ... I'm not working."

Noted by its absence is support by the child's father. Four of the teenagers' boyfriends are still attending school. Of the nine teenage mothers in this study, only five boyfriends admitted responsibility for fathering the children.

\section{(ii) Health care support}

According to Table 3, the most mentioned source of health care support and family planning is the local clinic. However, as already mentioned, this is seldom enough.

\section{(iii) Physical assistance}

Again, respondents rely on other children in the family for this assistance. This assistance comes randomly rather than being enduring. Such assistance depends on the availability and willingness of the other children. One elderly respondent who is looking after four young children, said: "Today this one is sick, I have to take him to the clinic. Then it's another one ... I have to look after the baby, too. When I ask the two boys to stay away from school to help me, they refuse."

Noted by their absence in rendering support are the husbands. In research done elsewhere, however, women mentioned husbands as their major source of support in daily childcare (Hollen, 1982:309; Kamerman, 1980:108). In another study (Weinberg \& Richardson, 1981:689), women reported problems with sharing responsibilities of child care with their spouses as one of the fourteen dimensions of stress in raising small children. This is a matter of concern on the part of Black women in this part of the country.

\section{(iv) Strength and sustenance}

Four respondents mentioned relying on God when the going became tough. One respondent said: "It was difficult ... It was dark. Today this baby has grown. All because of God." This suggests that even though the respondents experience difficulties, they are still able to transcend their situation.

\section{(v) Conflict resolution}

Several areas of conflict emerged from the respondents' accounts:

- Teenage mother for not doing her part in caring for her own child, contributing to the child's ill-health through engag- ing in prescribed acts, disregarding parental advice, manipulative behaviour and becoming too attached to the baby.

- The boy's parents for not rendering material support.

- The baby's father for failing to show parental responsibility.

- Husbands for not rendering financial assistance.

- The respondents' in-laws for interference.

- Supportive neighbours for becoming, in turn, an added burden.

Although all seven respondents admitted to experiencing conflict at times, only three mentioned dealing with it. The rest seem to avoid dealing with it at all. Another interesting observation is that all the respondents seem to expect from their husbands is financial-, not physical assistance.

\section{Conclusions and}

\section{Recommendations in the}

\section{form of Guidelines}

The results of this study show that the respondents require assistance from the formal and informal health care delivery systems. In fact, in the village in which the study was undertaken, nurses are the only formal group of health care professionals. Nurses also form the largest group of health care providers in South Africa. For this reason, they can contribute significantly to the promotion, maintenance and restoration of the mental health of mothers who take care of their teenage daughters' young children.

Figure 4.1 elicits how the advanced psychiatric nurse can assist mothers to mobilise resources in taking care of their teenage daughters' young children, by taking a holistic approach.

It is usually the teenager's mother who ends up taking over the parental role of her grandchild. In addition to the demands associated with the developmental tasks appropriate for her stage of development, she now also has to face childcare demands. These demands influence the patterns of interaction between the internal and external environment of the mother of the teenage mother, who fulfils the parental role in respect of the teenager's child. Depending on this pattern of interaction, the mother can experience either a sense of fulfilment or distress (physical, mental and spiritual).

The whole process in Figure 4.1 is dynamic and cyclic. This means that one strategy can influence many areas in the 


\section{Figure 4.1 : Psychiatric Nurses' assistance of mothers looking after teenage daughters' young children}

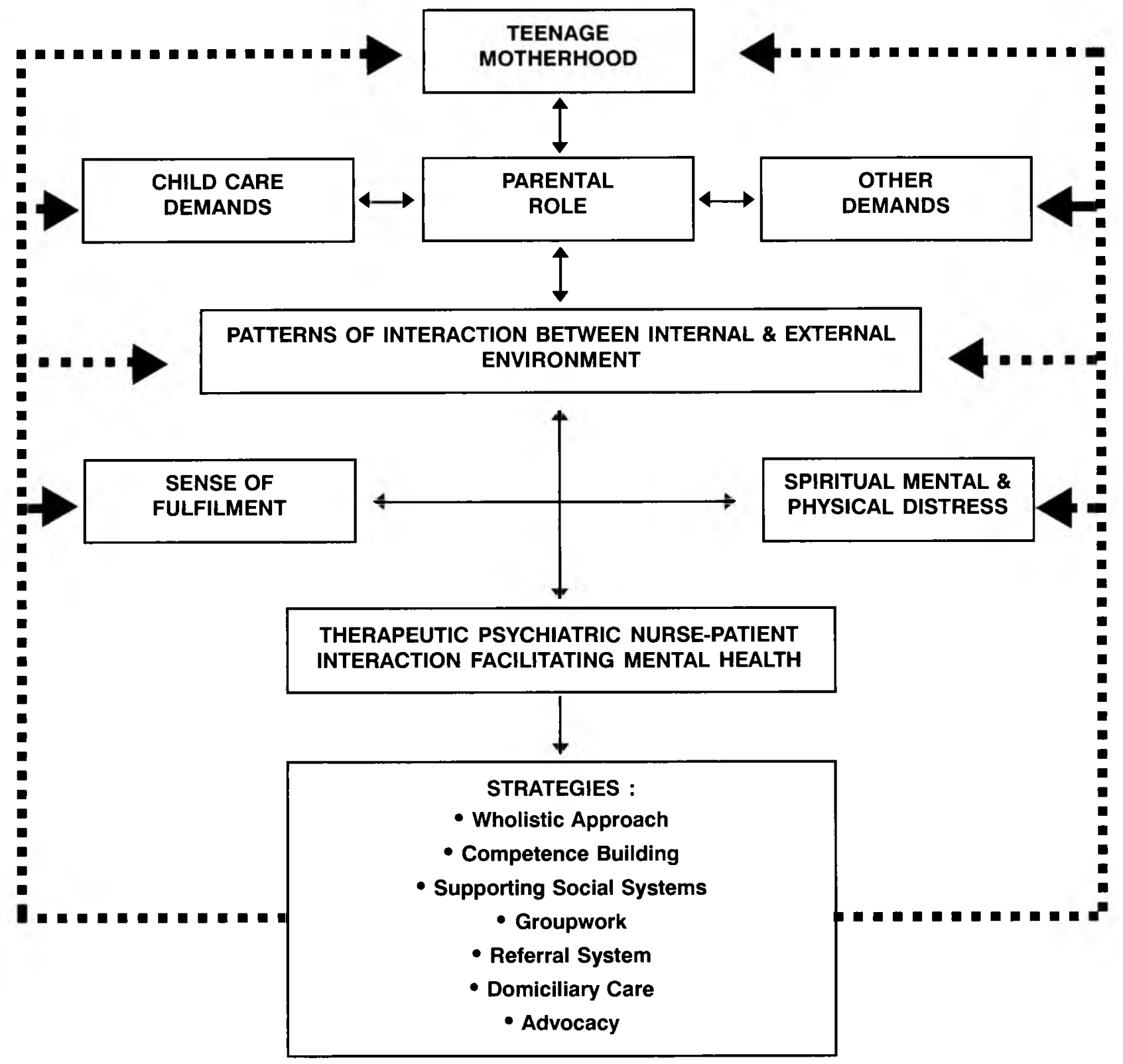

figure depending on the patterns of interaction between the internal and external environment of a respondent at a particular time. For example, the strategy of group work can lead to an increased sense of fulfilment, lessen mental distress and at the same time, strengthen the parental role.

Similarly, each strategy can be used in conjunction with other strategies. For example, the holistic approach can be used as a strategy in working with groups as a means of competence building. In addition, the strategies can be applied at any level of promotion, maintenance and restoration of mental health as an integral part of health. These strategies will now be briefly discussed.

- Holistic approach to nursing practice

In the implementation of the nursing process, the nurse can use a theory that considers a client in totality, that is body, mind and spirit as well as the external environment and patterns of interaction between the internal and external environment. An example of such a theory is the Nursing for the Whole Person Theory (Oral Roberts University: Anna Vaughn School of Nursing, 1990 1992:136-142, Rand Afrikaans University: Department of Nursing Science, 1992:36-41)

A client-centred approach is used so that the nurse-client interaction is negotiated and the nurse attempts to understand the client's explanatory model of health and illness (Wilson \& Kneisl, 1992:960). This is important as folk medicine was frequently utilised by respondents in this study.

\section{- Competence building}

This is a strategy that seeks to (i) in- crease the individual's or group's awareness of issues and events related to health and illness; (ii) increase in one's understanding of the dimensions of potential stressors, possible outcomes and alternative methods of doing things; and (iii) increase one's knowledge of where and how to acquire the necessary resources (Stuart \& Sundeen, 1991:257).

Methods that can be used for competence building are:

- education regarding stressors associated with parenting;

- cost-saving measures, such as nutritious yet low-cost baby foods, marketing of second-hand baby clothes, the practice of breast-milk expression, tending door-size vegetable gardens and anticipatory guidance about the needs of infants, toddlers and pre-school children (Liddell, 1989, chapters 11-13). 
The second method involves teaching of enrichment methods such as assertiveness training, problem solving, conflict management and stress management (Poggenpoel, 1995:54).

The third method involves teaching of other life skills, for example budgeting and time management skills.

\section{- Supporting social systems}

These systems have three elements: (i) aiding the individual to mobilise her own internal resources to overcome the emotional conflict of defective feedback; (ii) sharing of tasks, such as actual child care; and (iii) providing additional external resources such as money, refuge, problem-solving skills and advice (Caplan in Hollen, 1982:309).

The groups which can be established in the village or where a client can be referred to can be either informal or formal. Informal groups include friends, acquaintances, neighbours and members of the family. Formal groups are self-help groups with a constitution. It is important that the nurse matches the level and type of social support to the nature of the stressor (Stuart \& Sundeen, 1991:262).

\section{- Group work}

The nurse organizes groups of women who are taking a parental role in the lives of the young children of teenage mothers. The aims are: (i) to maximize the impact the nurse can make; (ii) to provide an opportunity for group participants to share experiences, discuss common problems, share solutions, express emotional distress and reduce isolation and loneliness expressed by respondents in his study (Kuipers \& Bebbington, 1990:55)

\section{- Effective referral system}

The nurse should establish a network and keep a file of names and addresses of all potential resourceful persons, such as psychiatric nursing specialists and consultants, agencies and organizations in the region, province and country. When the need arises, the mothers who are taking care of their teenage daughters' young children can be referred to these persons, agencies or organizations for support.

\section{- Domiciliary care}

Wherever possible, nurses should make home visits to mothers who are taking care of their teenage daughters' young children. This is important because some of the respondents in this study are elderly and sickly and, therefore, may not benefit from group work. The main objective here is to increase contact between the client and the health care sys- tem, and to reduce isolation. During home visits, the nurse can conduct education sessions, monitor the health of the family system, and hold family problem solving sessions (Kuipers \& Bebbington, 1990:67).

\section{- Advocacy}

The nurse can stimulate community action as well as influence government action by playing an advocacy role on behalf of mothers of teenage mothers. The objectives are to make society aware of its responsibility in respect of teenage pregnancy and parenting, by impressing upon it the impact thereof on the mental health of mothers of teenagers; to change community attitudes about child-rearing practices and to inform women about their rights.

The nurse and women can make representations to the Reconstruction and Development Program (RDP) forum in their village regarding the needs of mothering. The need for child care facilities, such as publicly subsidized day care centers and public school-based kindergarten and preschools.

This will leave mothers free to follow their developmental tasks appropriate to their stage of development and the necessary time off to rest.

Since respondents in this study derive a sense of fulfillment from the parenting role, a partnership can be formed between a publicly subsidized child care system where they can form a group of child minders and be paid for part of their services in cash or in kind. The nurse can also press for representation of this group of mothers in the RDP forums.

The nurse can play an advocacy role by pleading with the system, arguing and recommending a change that will benefit the clients (Leddy \& Pepper, 1989:379). One way of changing the system is to advocate for a team of mental health nursing specialists, multidisciplinary teams and private doctors to visit the village on a weekly basis (Fawcett, 1993:219).

\section{- Anticipatory guidance}

Conducting anticipatory guidance classes for pregnant teenagers can also help their mothers indirectly. One of the areas that caused conflict for the respondents in this study was the teenage mothers' lack of parenting skill. The mothers of teenagers can also benefit from these classes, as it will enable them to anticipate likely problems and develop solutions before their teenage daughters become pregnant.

\section{Conclusions}

This study arose from three observations. Firstly, that in most cases and amongst Blacks in particular, the young children of teenage mothers are parented by their grandmothers. This has become necessary to allow the teenage daughter to become equipped for a career/education.

The second observation is the absence of programs to support these grandmothers in the stressful role of parenting. Perhaps this can be attributed to the assumption that grandmothers are experienced parents. Related to this lack of programs for grandmothers is the third observation, namely the apparent lack of research studies on grandmothers as a target group, as well as silence on the part of the popular media.

\section{Acknowledgements}

Acknowledgement is given to

- The Human Sciences Research Council and University of the North West for financial support in completing this research project;

- The research respondents and all those who assisted by whatever means to the success of the project 
References

BALLENSKI, CB \& COOK, AS 1982: Mothers' perceptions of their competence in managing selected parenting tasks. Familv Relations. 31, 489-494.

BEAUTRAIS, AL; FERGUSSON, DM \& SHANNON, FT 1982: Family life events and behaviour problems in pre-schoolaged children. Paediatrics. 70: 774-779.

BOULTON, MG 1983: On being a mother. London: Tavistock Publications.

BRAILEY, LJ 1985: How mothers learn to cope. Nursina Times. 81 (30), 47-49.

BROOK-GUNN, J \& CHASELANDSDALE, $L$ 1991: Children having children: Effects on the family system. Paediatric Nursing, 20 (9), 467-481.

BURNS, N \& GROVE, SK 1993: The practice of nursing research: Conduct, critique and utilisation. Philadelphia: W.B. Saunders.

CRESWELL, JW 1994: Research design: Qualitative and quantitative approaches. London: Sage Publications.

GIORGI, A (ED) 1985: Phenomenological and psychological research. Pittsburgh: PA., Duquesne University Press.

GORDON, T 1990: Feminist mothers. Honk Kong: MacMillan.

HOLLEN, P 1982: Parents' perceptions of parenting support systems. Paediatric Nursing, September/October 1982.

KAMERMAN, SB 1980: Parenting in an unresponsive society. New York: The Free Press.

KOOMA, S 1992: Giving birth to Africa's big problem. Sowetan. April 24, p15.

KREFTING, L 1991: Rigor in qualitative research: The assessment of trustworthiness. American Journal of Occupational Therapy. 45 (3), March 1991.

KUIPEAS, L \& BEBBINGTON, P 1990: Working in partnership: Clinicians and carers in the management of longstanding mental illness. London: Heinemann.

LEIFER, M 1980: Psychological effects of motherhood. New York: Praeger Publications.

LIDDELL, LA 1989: Building life skills. South Holland Illinois: The GoodheartWillcox Co. Inc.
LOENING, W 1992: Adolescent pregnancy: A medical perspective on the consequences for mother and child. Sandra Burman \& Eleanor PrestonWhyte (Eds.) in Questionable Issue: IIleaitimacv in South Africa. Cape Town: Oxford University Press.

MILLER, BC \& MYERS-WALLS, JA 1983: Parenthood: Stresses and coping strategies in H.I. McCubbin \& C.R. Figley, (Eds.). Stress and the Familv. Vol. 1, Coping with Normative Transitions. New York: Brunnel/Mazel Publishers.

MOUTON, J \& MARAIS, H 1989: Basic concepts in the methodology of the social sciences. Pretoria: Human Science Research Council.

OJWANG, SB \& MAGGWA, ABN 1991: Adolescent sexuality in Kenya. East African Medical Journal. 68 (2), February 1991, 74-79.

21. OMERY, A 1983: Phenomenology: A method for nursing research. Advances in Nursing Science 5 (2), 4963.

22. POGGENPOEL, M; NOLTE, A; DÖRFLING, C; GREEFF, M; GROSS, E; MULLER, M; NEL, E \& ROOS, S 1994: Community views on informal housing environment: Implications for health promotion. South African Journal of Sociology. 25 (4), November 1994, 131-136

23. PRESTON-WHYTE, EM 1991: Teenage pregnancy in selected coloured and Black communities. Pretoria: Human Sciences Research Council.

24. PUSKAR, KR \& MARTSOLF, D 1993: Stress in rural families, in C.S. Fawcett. Familv Psvchiatric Nursing. St. Louis: Mosby.

25. SOMMER, K; WHITMAN, TL; BARKOWSKI, JG; SCHELLENBACH, C; MAXWELL, S \& KEOUGH, D 1993: Cognitive readiness and adolescent parenting. Developmental Psychology. 29 (2), 389-398.

26. STERN, PN 1989: Pregnancy and parenting. London: Hemisphere Publishing Corporation.

27. TAM, $K$ \& CHAN, $Y$ 1994: Validation of the parenting stress index among Chinese mothers in Hong Kong. Journal of Communitv Psvcholoav. 22, July 1994, 211-223
28. TSHOTSHO, NM 1994: Assessment of a psychiatric patient using the trans-cultural approach. Dissertation for Master Curationis degree. Port Elizabeth: University of Port Elizabeth.

29. UNGER, R \& CRAWFORD, M 1992: Women and gender. New York: McGraw-Hill, Inc.

30. VALMAN, HB 1993: ABC of one to seven. Cambridge: BMJ Publishing Group.

31. WASHINGTON, $V$ 1988: The Black mother in the U.S. in B. Birns \& D.F. Hay (Eds.). The Different Faces of Motherhood. New York: Plenum Press.

32. WEINBERG, SL \& RICHARDSON, MS 1981: Dimensions of stress in early parenting. Journal of Consulting and Clinical Psvchologv. 47 (5), 686-693

33. WILSON, H 1989: Research in nursing. New York: Addison-Wesley Publishing Company.

34. WILSON, MS \& KNEISL, CR 1992: Psychiatric nursing. California: Addison-Wesley Publishing Company. 